\title{
THE ROLE OF FLEXICURITY MODEL FOR DECENT WORK AND ECONOMIC GROWTH: LITHUANIAN CASE
}

Jadvyga Ciburiene ${ }^{1}, \mathrm{PhD} /$ professor

Kaunas University of Technology, Lithuania

\begin{abstract}
The aim of this paper is to show the importance of the labour market and employment in the conditions of globalization in the context of sustainable development. This paper evaluates the formation of sustainable development, its main features and sustainable development goals. This theme aims to examine the evolution of sustainable development goals and its fundamental values and to show the importance of labour market and one of its policies - flexicurity. The objectives of this article are: to characterize the sustainable development goals on the global, the European Union Member States (EU-28) and Lithuanian levels; to characterize the flexicurity of labour market policy and to make a comparative analysis of employment forms in Lithuania, Latvia, Denmark and the EU-28 in the period of 2005-2017. Data from Eurostat databases for the year 2005-2017 are used for the analysis. The method of base indicators (labour market employment rate, activity rate, unemployment rate and others indicators) comparison is used, whereas the first year (e.g. year 2005) of the analysed period is chosen as base year.

The analysis shows that economic modernization in the context of globalization in Lithuania is based on the main sustainable development goals and the EU-28 economic development targets. The comparison of main labour market employment forms in Lithuania, Latvia, Denmark and the EU-28 shows differences, which requires further research. The investigation reveals that in Lithuania and Latvia the flexicurity model is weak, unlike in Denmark and the EU-28.
\end{abstract}

Key words: economic development, sustainable development, labour economics policies, unemployment. JEL code: 013, Q01, J08, J6.

\section{Introduction}

The ongoing changes in the economic environment at a global level are driven by the globalization processes. Thus leading to increasing global integration among individual markets such as goods, services, capital, labour and so on (Aktan C., 2005). With the integration of countries around the world, obstacles of the mobility of goods, capital and people among countries are constantly diminishing. This has a positive impact on global economic growth and is expanding and deepening relations among economically developed and less developed countries. Economic growth and the reduction of inequality are one of the most important economic development goals at global level.

The country's economic growth is directly related to one of the most important macroeconomic indicators of the country - the growth of real gross domestic product and the indicator of the quality of life change. The results of the country's economic development are always linked to the labour market and employment. On the other hand, economic growth is linked to quantitative and qualitative changes (in economic sectors, economic activities, etc.) that are constantly evident in various fields. In scientific literature (Galiniene B. et al., 2007; Sakalas A., Savaneviciene A., Girdauskiene L., 2016), this is described as a targeted tendency of modern economy to dynamism, which manifests itself in the economy as a system. Dynamic changes in economic processes are related to the modernization of economic activities from various perspectives to the increasingly broadly based idea of sustainable development (Mikalauskiene A., 2014). In response to changes in the labour market security, the European Commission has put forward a new labour relations policy, i. flexicurity, the direction that determines flexibility and security in the labour market. This model is based on the Danish labour market experience, which summarizes high employment rates, high

${ }^{1}$ Corresponding author. Te.: + (370613 43624); fax: + (370 208757).

E-mail address: jadvyga.ciburiene@ktu.It 
employee mobility and high costs for active labour market policy measures (Ionete A., 2012; Kuodis R., 2015).

The essence of sustainable development as a long-term process is widely debated and analysed at national, regional and global levels and covers economic, social and ecological aspects. At the global level, the UN played a key role in the development and development of modernization processes, which can be summarized in six stages:

1. in 1972 for the first time, the UN Stockholm Conference has linked economic and ecological issues together and formulated the idea of sustainable development (Report of the United Nations, 1972);

2. in 1986, the UN Conference on Environment and Development in Ottawa discussed the World Security Strategy and described social justice as a factor determining "harmonious and equiTable development" (Ciegis R., Ciegis R., Jasinskas E., 2005);

3. in 1987, the UN World Commission on Environment and Development (WCED), headed by the Norwegian Prime Minister, Gro Harlem Brundtland, published a report entitled "Our Common Future" (1987), which highlights two important objectives: 1) the development objective of ensuring a good standard of living for all; 2) the goal of sustainability is to live with respect to the environment. It emphasizes the importance of such development, which would lead to the well-being of people not only in the present time, but also in the future;

4. in 1992, the UN Conference on Environment and Development in Rio de Janeiro adopted a long-term 21 action agenda to ensure a sTable environment and sustainable development across the globe; responsibly assess the role of consumption and responsible use of natural resources;

5. in 2000, the UN Millennium Summit was held in New York, where major changes were identified in eight directions, signed by the leaders of 189 countries around the world, characterized by the Millennium Declaration (2000);

6. in 2002 at the UN Summit in Johannesburg (Earth Summit on Sustainable Development), all member states were invited to set up long-term (2012-2022) programs to promote sustainable consumption and production. The meeting emphasized the importance of ways of production and consumption, their changes, mutual coordination in solving issues of sustainable development (Mikalauskiene A., 2014, p.13);

7. the development goals set by the Millennium Declaration (2000) face various challenges for their implementation. For this reason, the UN has announced a revised development agenda called the "Sustainable Development Agenda 2030" (Transforming Our World: the 2030 Agenda for Sustainable Development 2015), which formulates seventeen sustainable development goals that are closely related to the human factor, the labour market, employment and life level. This document was signed by 192 heads of state, and includes 17 goals:

1. eliminate all forms of poverty;

2. eliminate hunger, ensure food security and nutrition, and promote sustainable agriculture;

3. ensure healthy life and promote the well-being of all age groups;

4. ensure comprehensive and equiTable quality education and promote lifelong learning;

5. achieve gender equality and empower women and girls;

6. ensure access to water, sustainable management and sanitation for all;

7. ensuring everyone has access to affordable, reliable, sustainable and up-to-date energy;

8. to promote sustainable, inclusive and sustainable economic growth, productive employment and decent work; 
9. develop a resilient infrastructure, promote inclusive and sustainable industrialization and promote innovation;

10. reduce inequalities between states and between states;

11. make cities and people living in areas safe, resilient and sustainable;

12. ensure sustainable consumption and production patterns;

13. to take urgent action to combat climate change and its consequences;

14. conservation and sustainable use of oceans and marine resources;

15. to protect, restore, promote the sustainable use of terrestrial ecosystems, sustainable management of forests, combat desertification, stop land degradation, stop biodiversity loss;

16. promote peaceful societies for sustainable development, ensure access to justice for all and create effective, accounTable institutions at all levels;

17. strengthen implementation measures for the development agenda and revitalize the global partnership for sustainable development.

These ambitious goals have been raised to ensure that all three aspects of sustainable development (economic, social and environmental), including the level of employment that determines the standard of living in the region, are realized. Changes in the economic system (both internal and external) are always related to the economic activity, employment and income of the country's population in any sector or economic activity (Sakalas A. et al., 2016; Aktan C., 2005). Changesrelate to the direction of system development, the involvement of participants in the activities of organizations, and their performance. In the scientific literature (Stark O., 2004; Schiller B.R., Hill S., Wall S., 2013), it is noted that human capital determines that some countries are more socially and economically advanced than others, and social development of countries with better use and appreciation of human capital is more sustainable and the level of life quality is higher (Mannheim, 1980; Atkociuniene Z., 2008). The development of science and knowledge is one of the conditions for the development of society. The link between the higher education system and the labour market is ensured through knowledge, skills, competences, skills acquired in the study process in various fields. The level of education determines the qualifications of the employees and better conditions of employment. People, especially young people, are ready for the labour market to become economically empowered and create preconditions for sustainable development and increase employment rates in the country.

\section{Research results and discussion}

The analysis of the objectives of Transforming Our World: The 2030 Agenda for Sustainable Development (2015) shows that they are closely related to the human factor, employment and living standards. By combining the goals of the organization and the individual's activities, the growth of performance (qualitative, quantitative) is likely. In this respect, the eighth objective: "Promoting sustainable, inclusive and sustainable economic growth and productive employment and decent work" is particularly important. Sustainable Development Goals can be analysed as a way to modernize the economic development process.

It is important to note that the EU Treaty of Amsterdam (1997) sets out four horizontal priority objectives: 1) sustainable development; 2) gender equality and non-discrimination; 3) the information society and 4) regional development. For the first two goals, the EU member states have to comply with the requirements of structural support, and the third and fourth are to comply with the country's needs. 
In 2015, Lithuania has approved and signed the UN Resolution Transforming Our World: the 2030 Agenda for Sustainable Development (2015), which identifies 17 development goals. In addition, Lithuania identifies four priority areas for sustainable development: 1) reducing social exclusion and poverty; 2) healthy lifestyle, 3) energy efficiency and 4) climate change and sustainable consumption and production (Vazgauskaite J., 2016). Lithuania's priorities are in line with the concept of sustainable development, but the problem of emigration is particularly relevant in Lithuania, which often arises from low pay, ineligibility and low appreciation of employees. For this reason, the third priority of the EU Strategy - Europe 2020 - inclusive growth, based on the promotion of employment, ensuring social and territorial cohesion, is particularly relevant in Lithuania. In this respect, one of the most important EU objectives is, as shown in Table 1, increasing the employment rate to $75 \%$ in the age group 20-64 of population; increasing the level of investment to R\&D to $3 \%$. The aim is to reduce the number of early school leavers to $10 \%$, with at least $40 \%$ of young people having higher education in the age of 30-34. These targets are adjusted for each EU member state, depending on its level of economic development.

Table 1

EU-28 Europe 2020 targets

\begin{tabular}{|l|c|c|c|c|c|}
\hline No & $\begin{array}{c}\text { Member } \\
\text { States targets }\end{array}$ & $\begin{array}{c}\text { Employment rate of } \\
\text { population aged 20- } \\
\mathbf{6 4} \text { in \% }\end{array}$ & $\begin{array}{c}\text { R\&D } \\
\text { Expenditure } \\
\text { in \% of GDP }\end{array}$ & $\begin{array}{c}\text { Early school } \\
\text { leaving } \\
\text { decrease in \% }\end{array}$ & $\begin{array}{c}\text { Tertiary } \\
\text { education of } \\
\text { youth aged 30- } \\
\mathbf{3 4} \text { in \% }\end{array}$ \\
\hline $\mathbf{1 .}$ & EU-28 & 75 & 3 & 10 & 40 \\
\hline $\mathbf{2 .}$ & Denmark & 77 & 3 & $<10$ & 42 \\
\hline $\mathbf{3 .}$ & Latvia & 73 & 1.5 & 13.4 & $34-36$ \\
\hline $\mathbf{4}$ & Lithuania & 72.8 & 1.9 & $<9$ & 40 \\
\hline
\end{tabular}

Source: Strategy Europe 2020 targets

The change in the employment rate of the age group 20-64 according to qualification / education is analysed in the year 2005-2017, as shown in Table 2 below. The employment rate of Lithuanian workers according to qualification levels is comparable with the results of Latvian, Danish and the EU-28 in average. Three levels of qualification are compared: low level of qualification (equivalent to education at ISCED 0-2), average level of qualification (equivalent to ISCED 3-4) and high level of qualification (equivalent to ISCED 5-8). The employment rate in the EU-28 in the age group 20-64 of the low-qualified population decreased by $1.08 \%$ over the whole analysed period. The growth of employment rate in this qualification group started and continued only in the year 2016-2017. The employment rate in Lithuania of the low-skilled population in the age group 20-64 decreased by $5.36 \%$. The decline in employment in this staff qualification group took place throughout all of the analysed period. Employment rate of low-skilled population in 2005 in the EU-28 was in $3.4 \%$ higher than in Lithuania, while in 2017 it was higher than in Lithuania and this difference increased to $10.8 \%$.

Employment rate of average skilled workers in 2005 in the EU-28 was insignificantly $(0.3 \%)$ higher than in Lithuania, and in 2017 it was slightly higher and this difference increased to $2.9 \%$. In the EU-28 this indicator rose to $4.61 \%$ over the entire analysed period. In Lithuania the average level of employment of employees with medium qualification in the year 2005-2016 decreased by 0.87 , but in 2017 it increased by $1.75 \%$, so the trend over the whole period has been positive, although during the year 2005-2017 it increased slightly, e.g. $0.87 \%$.

Employment rate of highly qualified workers in the year 2005 in the EU-28 was $3.7 \%$ lower than in Lithuania, while in the year 2017 it increased to $6.1 \%$. The employment rate of highly qualified 
employees in Lithuania during the analysed period increased from $86.3 \%$ to $90.1 \%$, e.g. increase rate was $4.4 \%$. The employment rate of highly qualified workers in Lithuania exceeded the EU-28 average, which was $82.7 \%$ and $83.4 \%$ respectively.

As science and technology progresses, it is anticipated that the number of low-skilled employees will decrease by about $40 \%$, the average qualification will increase by about $20 \%$, and the increase of highly qualified workers will be by about $40 \%$.

Table 2

20-64 years old population employment rate by education, $\%$

\begin{tabular}{|l|c|c|c|c|c|c|}
\hline \multirow{2}{*}{ Indicator/Year } & $\mathbf{2 0 0 5}$ & $\mathbf{2 0 1 0}$ & $\mathbf{2 0 1 5}$ & $\mathbf{2 0 1 6}$ & $\mathbf{2 0 1 7}$ & Increase rate \\
\hline \multicolumn{7}{|c|}{ ISCED 0-2 } \\
\hline EU-28 & 55.5 & 53.3 & 52.6 & 53.6 & 54.9 & -1.08 \\
\hline Denmark & 62.5 & 62,6 & 59,2 & 61.8 & 60.2 & -3.68 \\
\hline Latvia & 50.5 & 45.1 & 53.2 & 54.8 & 56.7 & 12.28 \\
\hline Lithuania & 46.6 & 29.6 & 42.7 & 42.3 & 44.1 & -5.36 \\
\hline \multicolumn{7}{|c|}{ ISCED 3-4 } \\
\hline EU-28 & 69.4 & 69.8 & 70.7 & 71.6 & 72.6 & 4.61 \\
\hline Denmark & 78.9 & 77.8 & 78.4 & 79.1 & 78.9 & 0 \\
\hline Latvia & 69.5 & 61.8 & 69.4 & 69.1 & 71.1 & 2.30 \\
\hline Lithuania & 69.1 & 58.8 & 67.2 & 68.5 & 69.7 & 0.87 \\
\hline \multicolumn{7}{|c|}{ ISCED 5-8 } \\
\hline EU-28 & 82.6 & 82.4 & 82.7 & 83.4 & 84.0 & 1.70 \\
\hline Denmark & 86.2 & 85.4 & 85.6 & 85.6. & 85.4 & -0.93 \\
\hline Latvia & 83.6 & 80.1 & 85.1 & 86.5 & 86.9 & 3.95 \\
\hline Lithuania & 86.3 & 85.7 & 88.7 & 90.4 & 90.1 & 4.40 \\
\hline
\end{tabular}

Analysing the overall employment rate, we can see a positive change in the labour markets of the countries. The data in Table 3 show that the EU-28 EU strategy has not yet achieved its objective, although in 2005-2017 it has not yet reached its target level. The employment rate increased by $6.33 \%$ over the period. In Denmark after 2007-2008 the employment rate of the financial crisis declined and reached its lowest level in 2010, ie.75.8 \%. From this lowest employment rate in 2010, until 2017 it increased by $1.45 \%$. Although the employment rate has recently increased, the $77 \%$ employment rate target has not yet been reached. Latvia reached the employment rate target in 2016 and Lithuania - in 2015.

With the exception of 2017, the highest labour market activity rate during the period analysed was in Denmark. In the year 2017 Latvia had the highest labour market activity rate, which was $82.0 \%$. The highest growth rate during the analysed period was in Latvia and amounted to $7.19 \%$.

The lowest unemployment rate, as shown in Table 3, was in Denmark. As a consequence of the global financial crisis, unemployment rate in Denmark rose up and in 2017 has not yet reached the pre-crisis levels. The unemployment rate fell most in of the EU-28 and stood at $15.56 \%$. Unemployment rate in Lithuania in year 2017 decreased to $7.1 \%$. It was marginally lower than the EU-28 average, which in 2017 was $7.6 \%$. The unemployment rate determines the losses of the country's gross domestic product. Throughout the period under review the unemployment rate in Denmark was the lowest in the EU-28.

The Denmark labour market uses the flexicurity model that aims to combine labour market flexibility and security with government labour market regulation. This model is recommended by the European Commission, because with a flexible regulation of labour relations, a higher 
employment rate (Implementation on ..., 2008) is achieved. The most important principles of flexicurity are: 1) flexible working relationships based on employment contracts; 2) lifelong learning opportunities enabling workers to upgrade; 3) active labour market policies that provide preconditions for retraining; and 4) a well-developed social security system based on the loss of social security benefits.

Table 3

20-64 year old population labour market indicators, \%

\begin{tabular}{|l|c|c|c|c|c|c|}
\hline \multirow{2}{*}{ Indicator/Year } & $\mathbf{2 0 0 5}$ & $\mathbf{2 0 1 0}$ & $\mathbf{2 0 1 5}$ & $\mathbf{2 0 1 6}$ & $\mathbf{2 0 1 7}$ & \multirow{2}{*}{ Increase rate } \\
\hline \multicolumn{7}{|c|}{ Employment rate ( \% of population aged 20-64) } \\
\hline EU-28 & 67.9 & 68.6 & 70.1 & 71.1 & 72.2 & 6.33 \\
\hline Denmark & 78.0 & 75.8 & 76.5 & 77.4 & 76.9 & -1.41 \\
\hline Latvia & 69.1 & 64.3 & 72.5 & 73.2 & 74.8 & 8.25 \\
\hline Lithuania & 70.7 & 64.3 & 73.3 & 75.2 & 76.0 & 7.50 \\
\hline \multicolumn{7}{|c|}{ Activity rate (\% of population aged 20-64) } \\
\hline EU-28 & 74.3 & 75.5 & 77.1 & 77.5 & 78.0 & 4.98 \\
\hline Denmark & 81.7 & 81.5 & 81.3 & 82.1 & 81.3 & -0.49 \\
\hline Latvia & 76.5 & 79.6 & 80.5 & 81.2 & 82.0 & 7.19 \\
\hline Lithuania & 77.0 & 78.2 & 80.8 & 81.7 & 81.9 & 6.36 \\
\hline \multicolumn{7}{|c|}{ Unemployment rate( \% of labour force) } \\
\hline EU-28 & 9.0 & 9.6 & 9.4 & 8.6 & 7.6 & -15.56 \\
\hline Denmark & 4.8 & 7.5 & 6.2 & 6.2 & 5.7 & 18.75 \\
\hline Latvia & 10.0 & 19.5 & 9.9 & 9.6 & 8.7 & -13.00 \\
\hline Lithuania & 8.3 & 17.8 & 9.1 & 7.9 & 7.1 & -14.46 \\
\hline
\end{tabular}

Source: author's calculations based on Eurostat data

Flexibility in the labour market is brought by the combination of various forms of employment as shown in Table 4. A flexible labour market would make it possible to meet the growing demand for different qualifications in the country's labour market. The data show that full-time employment in the year 2017 was the most popular in Lithuania, accounting for $74.7 \%$ of all of the employed population in the age group 20-64. This form of employment increased the most in the analysed period in Lithuania - by $6.71 \%$.

The growth of the self-employment in the year 2005-2017 was the highest Latvia, with an increase of $27.58 \%$. This form of employment is most frequent in the EU-28, in the year 2017 it comprised $13.62 \%$ of the population aged 20-64 of total employment. But in the period of 2005-2017 it showed a downward trend. In Lithuania, this form of employment decreased by $24.04 \%$ during the analysed period and decreased by $5.72 \%$ in Denmark.

The part-time employment is most widely applied in Denmark and on average in the EU-28. The most significant increase in part-time employment in the analysed period is in Denmark and amounts to $20.11 \%$. In the EU-28 in average it increased by $13.33 \%$. In Lithuania and Latvia, this form of employment has a low popularity and accounts for only about a third of Denmark's level. In the EU28 the average temporary employment rate is the highest in comparison with other countries and stands at $13.4 \%$. In the year 2005-2017 in Denmark, this form of employment was the fastest growing - by $23.26 \%$ and in the year 2017 it accounted for $10.6 \%$ of the population aged 20-64 of the total employment. In Lithuania and Latvia this form of employment is decreasing. 
The main forms of employment, \%

\begin{tabular}{|c|c|c|c|c|c|c|}
\hline Indicator/Year & 2005 & 2010 & 2015 & 2016 & 2017 & Increase rate \\
\hline \multicolumn{7}{|c|}{ Full-time employment rate ( $\%$ of population aged $20-64$ ) } \\
\hline EU-28 & $64.5 *$ & 63.0 & 64.1 & 65.1 & 66.2 & 2.64 \\
\hline Denmark & $73.9 * *$ & 69.7 & 69.5 & 70.4 & 70.3 & -4.87 \\
\hline Latvia & $72.9 * *$ & 62.8 & 71.6 & 72.0 & 73.5 & 0.82 \\
\hline Lithuania & $70.0 * *$ & 63.4 & 72.1 & 74.0 & 74.7 & 6.71 \\
\hline \multicolumn{7}{|c|}{ Self-employment rate ( $\%$ of population aged $20-64$ of the total employment) } \\
\hline EU-28 & 14.52 & 14.54 & 14.01 & 13.88 & 13.62 & -6.2 \\
\hline Denmark & 7.69 & 8.39 & 7.73 & 7.61 & 7.25 & -5.72 \\
\hline Latvia & 9.21 & 9.74 & 11.5 & 11.83 & 11.75 & 27.58 \\
\hline Lithuania & 14.27 & 8.83 & 10.78 & 11.18 & 10.84 & -24.04 \\
\hline \multicolumn{7}{|c|}{ Part time employment rate( $\%$ of population aged $20-64$ of the total employment) } \\
\hline EU-28 & 16.5 & 17.9 & 19.0 & 18.9 & 18.7 & 13.33 \\
\hline Denmark & 17.9 & 21.6 & 20.9 & 22.3 & 21.5 & 20.11 \\
\hline Latvia & 7.3 & 9.2 & 7.1 & 8.3 & 7.5 & 2.74 \\
\hline Lithuania & 6.9 & 7.7 & 7.6 & 7.1 & 7.4 & 7.25 \\
\hline \multicolumn{7}{|c|}{ Temporary employment rate ( $\%$ of population aged 20-64 of the total employment) } \\
\hline EU-28 & 12.8 & 12.9 & 13.2 & 13.3 & 13.4 & 4.69 \\
\hline Denmark & 8.6 & 7.7 & 7.7 & 12.5 & 10.6 & 23.26 \\
\hline Latvia & 8.1 & 6.9 & 3.6 & 3.6 & 2.9 & -64.2 \\
\hline Lithuania & 5.3 & 2.3 & 2.0 & 1.8 & 1.6 & -69.81 \\
\hline
\end{tabular}

Source: author's calculations based on Eurostat data

\section{Conclusions, proposals, recommendations}

1) Sustainable development goals are analysed as the way of modernization of economic development, including labour market.

2) The study shows different levels of employment for different levels of qualification: low-skilled (equivalent to education at ISCED 0-2), medium-skilled (equivalent to ISCED 3-4) and highskilled (equivalent to ISCED 5-8). Employment opportunities for low-skilled workers tend to decline. Employment opportunities for medium and high-skilled workers are increasing.

3) Although Lithuania (2015) and Latvia (2016) reached the employment target rate for the age group 20-64 of population, it is lower than the EU-28 average.

4) Part-time employment in Lithuania and Latvia, compared to this form of employment in Denmark and the EU-28 average, accounts for only one-third of the total population of age group 20-64.

5) It has been noticed that in Lithuania and Latvia the temporary employment rate in the most active population age group of 20-64 years is decreasing. This trend is not in line with Denmark and the EU-28 temporary employment trends, which are growing.

6) The full-time employment share of the population aged 20-64 is the highest in Lithuania and Latvia, comparing with Denmark and the EU-28 in average. The analysis of the labour market situation shows that in the new EU-28 member states - in Lithuania and Latvia - employees give priority to full-time employment and avoid temporary work.

7) In further scientific research of the labour market flexicurity model aspect, it is expedient to analyse the active labour market policy measures and their impact in mitigating the consequences of unemployment and passive labour market policies - social security measures for the unemployed and their impact on the labour market. 
8) It is important that the definition of unemployment is questionable because the indicator of the unemployment rate is calculated in Lithuania by two institutions: 1) Lithuanian Employment Service under the Ministry of Social Security and Labour and 2) Department of Statistics of Lithuania. The differences are due to the fact that the Lithuanian Employment Service uses the number of registered unemployed persons in their calculations, while the Lithuanian Department of Statistics - uses a survey to find out the number of unemployed and actively seeking it. This might be the reason why miscalculations of statistical data arise, so the results of researches can be questionable. Therefore, it is important to use Eurostat data

\section{Bibliography}

1. Aktan, V. (2004). Perspectives on Economics, Politics and Ethics. Ankara: Seckin. p. 172.

2. Atkociuniene, Z.O. (2008). Ziniu vadybos poveikis darniam vystymuisi (The Impact of Knowledge Management on Sustainable Development. Information Sciences, 2008, No. 46, pp. 24-36.

3. Ciegis, R., Ciegis, R., Jasinskas, E. (2005). Concepts of Strong Comparability and Commensurability versus Concepts of Strong and Weak Sustainability. Engineering Economics. No 5 (45), pp. 31-35.

4. Eurostat data. (2018). available on-line at http://ec.europa.eu/eurostat/tgm/table.do?tab=table\&init $=1 \&$ languageen\&pcode $=$ tsdec 430 \&plugin $=1$

5. Galiniene, B., Melnikas, B., Miskinis, A., Valentinavicius, S., Barzdenyte, B., Stanikunas, R., Balciunas, N., Svetikas, K., Ragauskiene, E., Neciunskas, A., Albaityte, G., Stilinis, R. (2007) Ekonomikos modernizavimas: Nauji issukiai ir ekonomines politikos prioritetai (Economic Modernization: New Challenges and Priorities of Economic Policy). Vilnius: Vilnius University. p. 512.

6. Implementation on the Common Principlesof Flexicurity within the Framework of the 2008-2010 Round of Lisbon Strategy - Report by the Flexicurity Mission. (2008). Council of the European Union. Flexicurity Pathways: Turning Hurdles into Stepping Stones. Report by the European Expert Group on Flexicurity. p.10.

7. Ionete, A. (2012). The Woorlds of Flexicurity - Labour Market Policies in Europe. Annals of the University of Oradea, Economic Science Series. Vol 21, No. 1, pp. 133-138.

8. Kuodis, R. (2015). Lietuvoje vyrauja naiviausias poziuris i darbo rinka (Lithuania has a Naive Attitude towards the Labour Market). Veidas, 5, pp. 5-15.

9. Mannheim, K. (1980). Structures of Thinking. London: Routledge \& Kegan Paul. p. 292.

10. Mikalauskiene, A. (2014). Darnaus vystymosi paradigma ir jos raida (Sustainable Development Paradigm and it's development), Monografijos sudarytoja Dalia Streimikiene: Darnus vystymasis: Teorija ir praktika (In Monography selected by Dalia Streimikiene: Sustainable Development: Theory and Practice, Vilnius: Vilnius University. p. 408.

11. Millennium Declaration United Nations 55/2. (2000) Resolution adopted by the General Assembly (2000) Fifty-fifth session. Agenda item $60(b)$, available on-line at https://orangeprojects.lt/ uploads /structure/docs/570_e60d13295e5387 a91f93e55b91709604.pdf

12.Sakalas, A., Savaneviciene, A., Girdauskiene, L. (2016). Pokyciu valdymas (Management Changes). Kaunas: Technology. p. 402.

13.Schiller, B.R., Hill, S., Wall, S. (2013). The Macroeconomy Today. 13-ed. New York: McGraw-Hill/Irwin. p. 912.

14. Stark, O. 2004. Rethinking the Brain Drain. World Development 32(1), pp. 15-22.

15. Transforming Our World: the 2030 Agenda for Sustainable Development (2015). /RES/70/1), available online at https://orangeprojects.lt/uploads/structure/docs/616_f0344be4d69247a960d9f29e16311d16.pdf

16.Vazgauskaite, J. (2016) Lithuanian Sustainable Development Goals: Are We Properly Prepared? Newsletter. Subject: Sustainable Development Objectives, December, p .4-6.

17. Report of the United Nations conference on the Human Environment. (1972). United Nations. Stockholm. p.80. 